\title{
THEORIZING AGRICULTURE VALUE CHAINS: INTEGRATING SMALL HOLDER PRODUCERS TO OVERCOME HURDLES
}

\author{
Hena.M, Dr.Ushadevi.K. $N^{a^{*}}$ \\ ${ }^{a}$ Department of Rural Marketing Management, College of Cooperation, Banking and Management, Kerala Agricultural University, \\ Thrissur, Kerala, India, henashafeek@gmail.com \\ *Corresponding author.
}

Received: 28 October 2018, accepted: 31 October 2018, published: 3 March 2019

\begin{abstract}
Modern marketing techniques and restructured markets for agriculture products has made the small holder producers to fight against a number of consequences which they are actually not practiced or trained. As an alternative, new innovative practice like value chain approach has been identified in improving their ability to combat the restructured market conditions. This paper reviews the theoretical justifications and different viewpoints of value chains approach which can benefit the small holder producers in agriculture sector. A review on evidences from agricultural value chain experiences exposed the necessity of a tool or a business model like value chain approach to integrate the small holder producers to viable markets and to capitalize the immense opportunities in the markets, particularly for least developed and developing countries. The literature revealed that small holder producer can access international markets by establishing value chain networks and by building relationships in chain networks.
\end{abstract}

Keywords: agriculture value chains, producers, governance, networks, approaches

\section{INTRODUCTION}

Value chain, conceptualized by Porter (1985) is a strict business application and the framework helps to determine the current and potential competitive advantage for the firms and comprised of whole range of discrete, though interrelated, activities involved in the design, production and marketing of a product. In short, a value chain intends to maximize the benefits or value that could be generated out of the combined operation of all interrelated value chain actors. Global value chain analysis presents a theoretical frame work to comprehend the integration of firms into viable networks in markets (Gereffi, et al, 2001). Kaplinsky and Morris (2001) mentioned that in the era of globalization, the opinion of increase in income level gap in a country and between countries are well accepted. Earlier to this, Gereffi and Korzeniewicz (1994) also used the value chain concept to evaluate globalization. After reviewing the Global value chain studies, Reji (2013) made an opinion that the studies addressed the process of integration of developing country firms into the value chains of large firms in developed countries, looked at the relationships between firms, and its governance and upgrading practices to become more competitive. He doubted how much the new change in the market and the opportunities can be capitalized by the small producers in developing countries. The main sections in this paper are:

1) concept of value chains and the approaches in developing viable value chains; 2) agriculture value chains; 3 ) empirical evidences for agriculture value chains with summary and conclusions. 


\section{Concept of Value Chains and the approaches for viable value chains}

Hellin and Meijer (2006) defined value chains as "full range of activities which are required to bring a product or service from conception, through the different phases of production (involving a combination of physical transformation and the input of various producer services), delivery to the final customers, and disposal after use". Definitions for the value chain can be construed in two different ways: a narrow sense and in a broad sense. Value chain in a narrow sense consist of series of activities which executed within a firm to produce an output, where the producers to consumers are interconnected and each activity contributes an additional value to the end product. Dissimilar to the former view, value chain in a broad sense narrates it as a complex series of actions of interrelated actors like producers, processors, traders, service providers etc. This chain also explains the backward and forward linkages among the chain actors who are engaged in trading, processing, exporting to add proportional value to the final product (DFID, 2008).

The literature on concept of value chain approaches has divided into the three major research streams including the filiere approach ( Raikes et al. 2000), Porter's Framework (1985) and the Global approach by Kaplinsky (1999) and Gereffi (1994). DFID (2008) reported filiere as an instrument to evaluate the production system of agricultural commodities in developing countries and hence this approach has concentrated on the different practices involved in trade, processing and export of final product and its consumption. Kaplinsky and Morris (2001) mentioned that in the era of globalization, the opinion of increase in incomes gap in a country and between countries are well accepted. Before this, Gereffi and Korzeniewicz (1994) used the value chain concept to evaluate globalization. Global value chain analysis presents a theoretical frame work to comprehend the integration of firms into viable structure in market (Gereffi, et al, 2001).

Value chain approaches give an idea about the path in which the product and services moves along the value chain from the production end to the consumption end which may ultimately help to increase the livelihood situation of the groups engaged in agriculture. The key dimensions of Global Commodity Chains(GCC) were first documented by Gereffi (1994) as input-output structure, geographical coverage, form of governance and institutional framework. On the other hand, he couldn't suggest how to quantify these dimensions or what advantages can be gained by taking part in a commodity chain. Unlike the filiere approach which concentrated on agricultural commodities, the GCC approach highlighted the manufacturing firms and its economic integration internationally (Bair, 2005). Afterward, the Global Commodity Chain (GCC) approach was changed to an impressive form as Global Value Chain (GVC) analysis (Humphrey and Schmitz, 2000). Comparing with the earlier concepts and approaches, Global value chains looks into the governance factor, its relationships and value chain upgrading. "Buyer driven" governance relations and "producer driven" governance relations in value chains were reported by Gereffi (1999), where the former chains are implemented by large established businesses and the latter are directed by technology intensive firms. Further, Gereffi et al (2005) reported a new classification of governance relations as arm's length, modular, relational, captive and hierarchical, which forms the basis of governance relations. Humphrey and Schmitz (2002) devised different types of probable upgrading to increase the competitiveness of the participants in the value chain. Different types of upgrading includes: process upgrading, product upgrading, functional upgrading and inter-chain or sectoral upgrading.

\section{Agriculture Value Chains}

Economic development and growth in agriculture are interlinked terms, which are the targets of developed and developing countries throughout the years. High prices and untimely supply of farm inputs, poor quality of seeds and planting materials, the high incidence of pests and diseases, inadequate technical knowledge regarding pests and disease management, lack of market information, poor awareness about value addition, climate change, and unreliability of rainfall, high temperature, and environmental degradation are the notable challenges subsist for small holder producers. It is believed that agriculture growth and development results in poverty reduction globally while it also support the fact that agriculture alone cannot do a magic to erase the poverty and inequality from the world scenario. However, the search for an alternative solution attracted the policy makers in the setting up of agro industries. In a long run, agro industries maintained with successful value chains, can amplify considerably the rate and scope of industrial growth. After realizing the better prospects of growth in agro industries in developing countries, they have started to spent considerable portion of investment to support the production of agricultural inputs. Earlier value chains of agricultural 
products were left unattended and now policy makers identified the realistic possibilities of agricultural product chains to generate value added and employment opportunities (UNIDO, 2009).

Agro-value chains covers activities like product handling, processing, distribution and recycling at farm, rural and urban level to convert agricultural inputs to final product. In addition to these actions in successive stages, monetary value and information are exchanged and finally the value is gradually added (Silva and Filho, 2007). UNIDO (2009) staff working paper on agro-value chain analysis and development made the concept of value chains in agriculture more explicit and precise. Further, the paper added, agro-value chain analysis "highlights the need for enterprise development, enhancement of product quality and safety, quantitative measurement of value addition along the chain, promotion of coordinated linkages among producers, processors and retailers, and improvement of the competitive position of individual enterprises in the marketplace". About preparing a Value chain map, DFID (2008) expressed it as "a picture is worth a thousand words", because mapping a value chain illustrates a clear understanding of the range of operations, the participants and their relationships within the value chain.

Haggblade et al (2012) described value chain maps in their paper on A Conceptual Framework for Promoting Inclusive Agricultural Value Chains funded by International Fund for Agricultural Development (IFAD), as a schematic snapshot which illustrates the production function with the interconnection of raw material, product and information flows in the existing structure. Almost a similar viewpoint was expressed by European Commission (2011) in their working document on "Analysis and development of inclusive value chains: to support small scale producers to access agricultural markets".

\section{Empirical evidences for agriculture value chains from different countries}

\subsection{Mango Value chain in Sierra Leone}

Majority of the population of Sierra Leone depends on agriculture for their livelihood, while Mango cultivation brings in food and nutritional security for their rural population. Communities living around the Outamba Kilimi National Park in Sierra Leone experience every year a notable loss in their income due to lack of awareness about post harvest handling and processing of Mango. This has failed the Mango producers from demanding better prices for their produce by meeting the required quality standards. The identified value chain network participants includes: 1) nursery producers 2 ) fresh mango producers,

3) harvesters and assemblers, 4) processors and 5) traders. The chain network is not fully developed to its capacity and as a result the actors faced constraints in diverse forms such as inputs shortage, lack of training on mango production and post harvest practices, poor market information and inadequate network relationships to grab and share opportunities in the market. Moreover, poor road network add the burden of high transportation cost to mango producers. Mango production and value addition in Sierra Leone can be increased by a suitable value chain network with better relationships within the actors, as well as community-based appropriate strategies to be adopted to capture new opportunities for improved market expansion and forest conservation (Arinloye et al, 2017). This will help to tap the maximum potential of the mango cultivation through flow of information, knowledge and communication and finally, can achieve competitiveness along the value chain integration.

\subsection{Coffee Value Chain in Karnataka, India}

Domination of the Coffee Board of India in marketing of coffee was adversely affected after the liberalization policies. Coffee growers retained the freedom to sell their produce either as uncured or cured form to the domestic dealers or exporters. As usual, intermediaries started controlling the coffee marketing with their influence and compelled the small producers to sell their coffee in low price. Hence, only a negligible amount of final product has reached the small producers in the value chain. Additionally, producers face different negative situations throughout the production and marketing practice in Coorg district in Karnataka. The coffee from Coorg transferred to international households through different actions carried out by various actors: producers, hullers, agents, curers, exporters, roasters and retailers and finally consumers (Kodigehalli, 2011). Coffee consumption region are very much attracted by popular brands of coffee and subsequently, coffee value chain follows a buyer driven governance structure, mostly dominated by roasters. 
Requirements are mainly influenced by the consumption habits and roasters' organizations and the information flow has been limited to the intermediaries only. Direct access of Indian coffee to international market has restricted by poor quality and low quantity of supply of coffee. Apart from the aforementioned challenges, innovations through upgrading activities, collective action of the producers can revamp the chain to higher profit margins favorable for the growers. Moreover, necessary efforts are required to permit the proper flow of market information and technical knowledge throughout the chain and to lessen the intermediaries' power to execute control in the coffee value chain. Certified and specialty coffee's quality standards created by global buyers forbid the entry of coffee growers who are deprived of resources and skills to enter these markets.

\subsection{Vegetable Value Chain in Ethiopia}

Vegetables producers in Habro and Kombolcha Woredas of Oromia Region in Ethiopia have to overcome the challenges like non availability of modern input supply, high post harvest losses, limited access to market, unattractive price of vegetables, inadequate storage and transportation facilities, vegetables with less quality and the illegal trade to Somalia (Woldesenbet, 2013). The main chain participants are input suppliers, vegetable producers, collectors, wholesalers, retailers, exporters and consumers. As the chain expands, vegetables pass through many intermediaries with little value being added before reaching the end users. Governance power in the chain structure concentrates around the wholesalers and exporters and they obtain the major share of profit. Marketable surplus depends mainly on market information and vegetables production, especially in the case of tomato. Therefore, policy aiming at increasing farmers' access to modern inputs, developing and improving infrastructure, gender consideration, cooperative development and improving extension system are recommended to accelerate the chain's development.

Horizontal linkages are common among collector and wholesalers. Overall, the governance of the vegetables value chain is buyer driven with minimum trust between various actors. The smallholder farmers are not organized and are not governing the value chain. Consequently, they are price takers and never negotiated the price due to fear of post harvest loss, in case the product is not sold.

\subsection{Black Pepper Value Chain in India}

Black pepper mostly grown in home gardens in Kerala, as intercrops and now most farms has senile and unproductive crop which need to be replanted. The requirements for Kerala Pepper farmers are: 1) shade tolerant high yielding varieties suitable for Kerala, 2) farmers to be aware about scientific crop management practices to ensure better productivity of the crop, 3) ensuring planting of improved high yielding varieties like Panniyoor 1 (world's first hybrid pepper which performs well under open conditions) to Panniyoor 8 depending on availability of sunlight, proper and scientific crop management, 4) ensuring prophylactic measures for pest and disease management, 5) promoting good agricultural practices and a more regulated system of planting with standards of uniform height will be helpful in improving overall production and productivity. Proper awareness to farmers on post harvest handling and value addition of pepper also can help them to realize better income for the farmers (Rageena, 2014). Quality management is not the major problem in crop like black pepper, after the process of harvesting the berries are dried in the drying yards, so as they turn in to black colour and loose moisture. No sample farmer was doing white pepper production. The dried seeds are cleaned and are been stored by using either plastic or gunny bags. No grading was followed at the farm level. The packed produce were either sold or stored by the farmer depending on the prices prevailing in the market. Most products change hands many times before they reach the final consumer. Stakeholders transform, store, and transfer or market the product, adding to its value at each step in the process. In black pepper value chain the major actors involved include input supplier, farmer, trader, wholesaler, retailer, processor and consumer.

\section{Conclusion}

Agriculture value chain analysis is an inclusive analysis to assist small holder producer of less developed and developing countries to stimulate economic growth of poor (Haggblade et al, 2012). Raju and Singh (2014) pinpointed the significance of pro-producer agriculture value chain and further, it can be a way for poverty reduction and social development. They also highlighted the necessity of small farmer integration, small holder agriculture viability, and 
collaboration across chain actors and importance of rural advisory and support services to farmers especially, in case of market information and innovative production and processing techniques. Aforesaid evidences from different countries also supported the need for proper flow of market information and farmers effort to overcome the challenges associated with modern marketing situations. Likewise, it is equally important to strengthen the value chain relationship between small holder producers and other actors in the chain through mutual benefit and cooperation. The final impacts for smallholder farmers would be to have food security, as well as a sustainable income and environment. They should access international markets by establishing viable agriculture value chains by building relationships in chain networks to survive the restructured markets in the modern era.

\section{REFERENCES}

Arinloye, A.D.D., Degrande,A., Hotegni,V.N.F., Asaah, E., Bockarie, R., \& Nyemeck,J.B. (2017). Value chain development for mango (Mangifera indica) around Outamba Kilimi National Park in Sierra Leone: constraints and opportunities for smallholders .Agriculture and Food Security, 6(14), 1-13. :doi:10.1186/s40066-017-0092-x

Bair,J.(2005). Global Capitalism and Commodity Chains: Look- ing Back, Going Forward. Competition and Change, Vol. 9, No. 2, pp. 153-180. doi:10.1179/102452905X45382

Da Silva, C., \& Filho, H.M.(2007). Guidelines for Rapid Appraisal of Agrifood Chain Performance in Developing Countries, Agricultural Management, Marketing and Finance ,Occasional Paper, No.20,FAO, Rome.

Department of International Development. (2008) .Making Value Chains Work Better for the Poor: A Tool book for Practitioners of Value Chain Analysis. Retrieved from http://valuechains4poor.pbworks.com/f/V4P+Toolbook+v3+Final+-+Part+1.pdf

European Commission. (2011). Analysis And Development Of Inclusive Value Chains To Support Small-Scale Producers To Access Agricultural Markets. Retrieved from https://ec.europa.eu/europeaid/sites/devco/files/study-inclusive-valuechains-201111_en_5.pdf

Ganapathy,M.S., Naveenkumar, H. S., Murthy,M.M \& Rajshekaramurthy, S.(2014). Value Chain Analysis of black pepper in Karnataka. International Journal of Sales and Marketing Management, Vol. 3, Issue 2, June-July 2014, 13-18

Gereffi, G. (1994). The organization of buyer driver global commodity chains: How U.S retailers shape overseas production networks, 95-122 In: Gereffi ,G and Korzeniewicz.M (eds.): Commodity Chains and Global Capitalism, Praeger Publishers, Westport, CT.

Gereffi, G., \& Korzeniewicz, G. (Ed).(1994). Commodity Chains and Global Capitalism, Praeger:London.

Gereffi, G., Humphrey, J., \& Sturgeon, T. (2005). The Governance of Global Value Chains. Review of Political Economy, 12 (1): 78-104.

Gereffi, G., Humphrey, J., Kaplinsky, R., \& Sturgeon, T. (2001) . Introduction: Globalisation, Value Chain and Development, IDS Bulletin, Vol. 32, No. 3, pp.1-12. doi:10.1111/j.17595436.2001.mp32003001.x

Haggblade,S.,Theriault,V., Staatz,J., Dembele, N., \& Diallo,B.(2012). A Conceptual Framework for Promoting Inclusive Agricultural Value Chains, International Fund for Agricultural Development, Michigan State University. Retrieved from https://pdfs.semanticscholar.org/89c8/10551b608805e843dc27b6cfdc4cb9d4dad2.pdf.

Hellin, J., \& Meijer, M. (2006). Guidelines for value chain analysis. FAO. Rome ,Italy. Retrieved from http://www.fao.org/3/a-bq787e.pdf

Humphrey, J., \& Schmitz,H.(2000). Governance and Upgrading: Linking Industrial Cluster and Global Value Chain Research,Working Paper No. 120, Institute of Development Studies, Brighton. 
Humphrey, J., \& Schmitz,H.(2002). How Does Insertion in Global Value Chains Affect Upgrading in Industrial Clusters?” Regional Studies, 36 (9), 1017- 1027. doi:10.1080/0034340022000022198

Kaplinsky, R. (1999). Globalisation and Unequalization: What Can Be Learned from Value Chain Analysis. Journal of Development Studies, 37(2): 117-146.

Kaplinsky, R.,\& Morris,M.(2001). A Hand Book for Value Chain Research. Institute of Development Studies, University of Sussex, Brighton.

Kodigehalli, B. V.( 2011). Value Chain Analysis for Coffee in Karnataka, India. MSc Thesis, Ghent University in Collaboration with Wageningen University.Retrieved from https://lib.ugent.be/fulltxt/RUG01/001/789/918/RUG01001789918_2012_0001_AC.pdf.

Porter, M.E.(1985). Competitive Advantage: Creating and Sustaining Superior Performance,The Free Press, New York.

Raikes, P., Jensen,M., \& Ponte,S.( 2000). Global commodity chain analysis and the Frencfiliére approach: comparison and critique. Economy and Society, 29 (3): 390-418. Retrieved from https://researchapi.cbs.dk/ws/portalfiles/stefano_ponte_global_commodity chain pdf.

Regeena, S. (2014). Economic Analysis of Black Pepper Cultivation in Kerala. International Journal of Science and Research,5(2), 594-596.

Reji, E.M.(2013). Value Chains and Small Enterprise Development: Theory and Praxis, American Journal of Industrial and Business Management, 3, 28-35. doi.org/10.4236/ajibm.2013.31004.x

United Nations Industrial Development Organization.( 2009). Agro-value chain analysis and development: a staff working paper, Vienna. Retrieved from https://www.unido.org/sites/default/files/2010-

02/Agro_value_chain_analysis_and_development_0.pdf.

Woldesenbet, A.T. (2013). Value chain analysis of vegetables: the case of habro and kombolcha woredas in oromia region, Ethiopia. MSc Thesis, Haramaya University, Ethiopia. Retrieved from http://www.academia.edu/32829465/

Raju, K.V \& Singh, V.K. (2014). Producers' Collectives in Sustainable Agri-value Chain. Retrieved from http://www.ksrm.ac.in/wp-content/uploads/2014/ 